\title{
Venezuela's communication dynamics in rejection of humanitarian assistance from United States of America
}

\author{
Kumajaya ${ }^{a, 1, *}$ \\ ${ }^{a}$ Universitas Gadjah Mada, Jl Sosio Yustisia, Yogyakarta 55281, Indonesia \\ ${ }^{1}$ kumajaya1987@gmail.com \\ * corresponding author
}

ARTICLE INFO

Article history

Received 2019-03-26

Revised 2019-05-23

Accepted 2019-05-28

Keywords

International Communication

Political Communication

Communication dynamics

Humanitarian

Venezuela

\begin{abstract}
This paper aims to find out how the communication dynamics by the Venezuelan government when dealing with humanitarian assistance provided by the international community, especially the United States. Venezuela is colaps, the international community including the United States wants to provide assistance to them, but the president of Venezuela, Maduro, refuses the aid. This research method uses interpretative case study methods. According to Casel and Simon, qualitative methods are social science research methods that attempt to accurately describe and interpret the meaning of symptoms that occur in a social context The United States had to continue and improve diplomatic leadership and assistance in response to the Venezuelan.
\end{abstract}

This is an open access article under the CC-BY-SA license.

\section{Introduction}

Currently under the leadership of Nicholas Maduro and the Authoritarian Venezuelas Socialist Party (PSUV), Venezuela is in the political crisis. Maduro was elected in 2013 after the death of Hugo Chavez (ruling in Venezuela 1999-2013). Maduru uses trials, security forces, and electoral councils to suppress opposition. On 20 May 2018 Maduro returned to power in Venezuela after winning the elections. The Maerika states, the European Union and some other Western countries do not recognise the legitimacy of its leadership. They looked at the National Assembly as the only democratic institution in Venezuela, when his inauguration of many demonstrations occurred to them that Maduro had provided a variety of political prisoners to honour the National Assembly led By the opposition. The United States and the international community continue to encourage Venezuela to transition to a new government. Venezuela is also experiencing economic crises, hyper inflation, food shortages and drugs that lead to the humanitarian crisis [1].

President Maduro blamed the sanctions made by the United States for the matter, while conditioned on the acceptance of food aid for support for his government and the control of military controls over the economy. He argues that Venezuela will attempt to restructuring its debts, even though it does not seem possible. Legal demands on the unpaid and the asset of the company's national assets of Venezuela.

In addition to preoccupied with humanitarian crisis problems, Maduro was accused of manipulation at the time of the last elections ranging from the regional level to the center to defend its power as president of Venezuela. The Internasinal community was split into three parts: the antiMaduro group that wanted to overthrow Maduro from its power. The moderate group wanted Maduro to improve the governance system without losing Maduro from office. and the support 
group Maduro who helped to support what Maduro was to strive for today, they are China, Russia and Cuba [2][3].

The United States has historically had close ties with Venezuela, as they were the main suppliers of oil to the United States. It would but the relationship deteriorated as Chavez came to power and is now continued by Maduro. United States of America to the human right and Democracy in Venezuela. also lack of state cooperation on counter-narcotics and counter-terrorism attempts. United States democracy and human rights funding amounted to fifteen million dollar in 2011 for support the citizens. The Trump government has used targeted penalties to Venezuelan officials responsible for violations of human rights, damaging democracy, and corruption as well as in individuals involved in drug trafficking. Since 2017 governments have imposed a broader set of sanctions to restrict the access of Venezuela to the United States financial markets and prohibit transactions involving Venezuela's currency. The administration provides nearly $\$ 97$ million in humanitarian aid to close neighbor countries protecting millions Venezuelan refugees [4].

Therefore in this paper the author would like to present some of matters relating to the dynamism of communication related to the humanitarian assistance carried out by Venezuela gevernment.

\section{Theoritical Framework}

\subsection{The Crisis is More Bigger}

Like in condition of war, venezuela have a big problem in humanitarian crisis that causes people's excectises in bulk. no food and drug o, hyper inflation, high tension of crimes in every where whole countri, children died cause not enough nutrition, continuous power outages, suppression have caused millions of people Venezuela left the country for the last two years. Nearly $90 \%$ of Venezuela's territory falls below the poverty line da The true true middle class disappears can not even eat more than once a day. Seeing the elderly man picking up food from the trash has been be the common Emms in the territory of Venezuela. Even the quality of health there very severe until until the UN also mentions the babies born in Syria have a greater chance of life than those born in Venezuela today. In Venezuela, the working person must be in an ektram with unpaid salary, although the salary is not enough to buy food for their own families. If there is a citizen of Venezuela who falls ill then the most appropriate choice is to pack and leave the country [5].

The collapse of Venezuela's economy in a decade is because inflation reached 13,000\% in 2018 and gross domestic product shrank by almost $50 \%$, industrial industry shrank to the lowest level in 30 years. Meanwhile the Maduro government ran out of money to pay debts to international bonds. Despite desperate efforts to receive unauthorized international assistance from China and Russia without the blessing of the National Assembly, the tort remains unavoidable. In addition to enforcement actions against Venezuela, including the seizure of oil assets abroad, it is only a matter of time [6].

While the dynamics of international politics can benefit the Venezuelan President, regional and other countries in the international community increasingly pushing for a return to democracy which includes Maduro's departure from power. For example more than 50 countries do not recognize the Victory Maduro election in May 2018. But the real test is whether the international community recognizes Maduro as President. The current debate is how many foreign actors are disturbing to take care of Venezuela's internal affairs. Efforts by failed attempts by international mediators to negotiate political resolution have confirmed the view that Maduro has endeavored for the long term [7].

The combination of economic collapse and state-led suppression has mendorongjutaan Venezuelan residents leave its homeland in the last three years and will still continue to increase in the next twelve months. Venezuelan refugees put significant pressure on neighboring countries. Last year's Colombian neighbouring Venezuela was involved in the aftermath of the refugee crisis, which brought about anti-immigrant sentiment because it felt that land work was taken by immigrants. Brazil, Ecuador and Peru have also expressed a state of emergency [8]. 


\subsection{USA - Venezuela Relationship}

The United States and Venezuela basically have very good relations in the past, Venezuela has even become one of the main oil suppliers for the United States. As an industrial country that needs oil to revitalize the economy and prosper its people, Venezuela's willingness to supply oil to the United States proves how good relations between the two countries in the past. But all that changed when Hugo Chavez came to power in 1999, he cut off the supply of oil to the United States and issued a series of policies that made relations between the two countries worse, after the Venezuelan leadership fell to Maduro, he continued what Chavez had done.

In fact with the humanitarian crisis that is now being experienced by Venezuela, America has the opportunity to return to having good relations with Venezuela even though it must result in Venezuela having a new President, moving the current position of Maduro. The United States can choose the same goal. The United States Organization (OAS) can be the best opportunity to change the system in Venezuela through methods that maintain agreement from Venezuela and the international community, acting America can directly lead to unpopularity, but working through international organizations can avoid this tension. The United States could maximize the role of OAS in improving Venezuela's domestic conditions. The United States has a more robust and robust system of countries than in Venezuela that makes a lack of corrupt practices there, but it cannot be found in Venezuela [9][10].

Perhaps the United States could not support Maduro and his reign. If you think situatiun in Venezuela for today will make disconnecting diplomatic relations until Maduro leaves its power can be the right choice. The United States also has a pengalamans aat attempting to overthrow the Chilean president of the day. The United States provides moral and financial support for Anti-Adelle activists in Chile. The support was successful and opened opportunities for the United States and other international communities to improve Chilean conditions. But whether similar conditions can be implemented in Venezuela? Conditions in Venezuela differ slightly and more have complications because there are not very few people in Venezuela who have the support of padaMaduro although there is already a tragic thing that happened today in Venezuela [11][3] .

But as soon as the United States should still pursue repairs in Venezuela without causing more unwanted effects. Feared if there is a military approach that is done to drop madurothen there will be a community resistance that will bring more morbans of the soul and add to the problem of the humanitarian crisis that has now occurred [12].

Moreover, Maduro has held military exercises involving tens of thousands of soldiers and civil society. They are facilitated for gun lifting exercises while performing war simulation and rescue missions. Indeed, this step was taken by Maduro to get negative highlights from various parties in the country and abroad, including its own community. However what this Maduro does can not be underestimated, can be a serious problem if the United States correctly intends to use a military approach facing Venezuela. However, Maduro is also unlikely to do military preparations because he is not like Chavez. Chavez with his hard attitude is still able to regulate the economy of the country and the people in his time can still get a food that is worthy of a term with other countries, but the same condition is not found in the reign of Maduro, the country And can not provide the basic needs of the community [13].

\section{Method}

This research method uses interpretative case study methods. According to Casel and Simon, qualitative methods are social science research methods that attempt to accurately describe and interpret the meaning of symptoms that occur in a social context [14]. In a sense, that this method will emphasize efforts to interpret and not quantify the data collected. This is due to various difficulties in conducting interviews with the perpetrators, this study is more oriented towards library studies and is not supplemented by in-depth interviews with experts, namely by analyzing a series of statements by Venezuelan government officials and statements from international organizations that had offered assistance, and to assess or not authoritarianism influences the level of acceptance of aid in Venezuela, researchers will scan political and economic news in the country during 2013 to 2018. 


\section{Results and Discussion}

There are many international communities that participate in the matter of Venezuela, ranging from Maerika states, European Union, Hungga United Nations.. Each of them is not an amateur but has a lot of experience taking care of various humanitarian crisis issues around the world [15]. They just need to communicate and strengthen each other's coordination to avoid overruling the international law and instead result in the emergence of new dictator dictators and new humanitarian crises. Because the original goal of the United States alongside the United international community in Venezuela was to solve the problems that existed there instead of adding new problems [16].

This is why the policy taken should be detached from the various interventions [5]. The United States also has a good track record of using military approaches. Iraq is a real example, where the United States after using military approaches to Iraq resulted in destruction that they could not improve to this day. If Iraq alone is actually an unresolved problem until today, the fate of Venezuela is greater than that of Iraq and also has a much less people with Iraq [17]. The Security Council of United States also has to supervise bids coming from China and Russia and Cuba. Because of their recorded allies close to Maduro. Avoid the more severe humanitarian crisis with a military approach but to carve out a political crisis due to the strong power of Maduro causing the current humanitarian crisis [8].

China and Russia are listed as the two countries whose international assistance is accepted by Venezuela when other internationalized assistance is rejected, This aid is what makes Venezuela can still breathe even if the condition is currently battered. Of course, there are consequences and communication between these countries, not only the case of giving state operational assistance on Maduro alone [18]. China gets the right to take on the natural resources owned by Venezuela from the help he gives [19]. Similarly Russian, had the opportunity to manage inverstation and the oil fields owned by Venezuela as an expression of gratitude for the assistance given to Venezuela as did China [20]. Also important for the leaders of Venezuela is the support of China and Russia in the United Nations Security Council, where these countries have been able to block the efforts of the United States against Venezuela [21]. But America still seeks to incriminate Venezuelan steps by attempting to ensnare using repressive action allegations against demonstrators, as well as illegal detention of political opposition and opponents, and the torture of prisoners [22].

These allegations have been filed into the International Criminal Court (ICC) with the support of several other Latin American countries, and some European countries. ICC followed up this report and made it as one of the serious studies because of the violence made by the State against its people and human rights violations. Not only is this indictment, but the United States is also granting the ICC a pressure to allow Venezuela to open up opportunities for the United States and other donor countries to enter humanity for the tragedy that occurs, Who have made millions of Venezuelan people suffer from [23].

In addition to things that are political, ideological affairs also accounted for the dynamics of the Latin American region. Venezuela as one part of Oenganut Bolivarianisme and is surrounded by socialism, especially since the leadership of Hugo Chavez which is then continued by Maduro at this time, is certainly not able to easily give confidence to The United States and other Western countries labeled capitalist to enter and interact with its citizens. The war of ideology also has an effect on this situation. In principle, ideology is a collection of ideas, the idea was then accumulated and formally written into a state reference.

This is reflected in the difference in orientation between Venezuela and donor countries, namely capitalism which is at odds with nationalism-socialism. Based on the constructivism paradigm, it is explained that humans are a medium that acts to construct social reality. That Bolivarianism was conceived by the founding figures of Venezuela had an influence on national interests which influenced the behavior of President Maduro and the previous regime in making decisions.

Leadership has an important role to support the achievement of national interests because in the third world country group, leadership has the character as an initiator in uniting institutions or community groups to build shared ideals[24]. The success of Nicolas Maduro in assuming the position of president turned out to be a benchmark for various policies that were anti-capitalism leading to liberalism. It seems that this policy tends to prioritize people power, but actually what is 
formed is liberalism, one of which is by making it easier for foreign companies to continue with the provision of control and control so that it can benefit development in Venezuela.

In his leadership Nicolas Maduro also developed economic cooperation, namely trade not by positioning himself as a pragmatic recipient of foreign aid with various world countries, including with the United States, India and China as Venezuela's largest export destination. Then in other fields, namely defense and security under the leadership of Nicolas Maduro also carried out cooperation with Russia in the procurement of defense equipment, including Sukhoi and small arms fighter types [25].

The Venezuelan government also expressed their solidarity with Argentina over the ownership of the Malvinas Islands, South Georgia and the South Sandwich which have been under the control of the British government since 1833. This is a manifestation of Chavez's determination to oppose all forms of imperialism as Simon Bolivar aspires. The Venezuelan government asks the disputing parties to comply with the UN General Assembly resolution which requires the British government to negotiate to find a peaceful and appropriate solution to resolve the problems of islands in South America [26].

Foreign decisions on leadership and ideology then bring consequences, namely Venezuelan foreign policy that will conflict with the interests of Western countries. Under the leadership of Nicolas Maduro, indeed the United States is still the main export-import partner for Venezuela, but this does not occur in the allocation of foreign aid and humanitarianism.

Nicolas Maduro's government considers that Venezuela will later become the object of influence / hegemony from actors / donor countries, so that the positive values mandated by the founding fathers will be abandoned, including Bolivarianism, Chauvinism, Marxism and Socialism. This is the reason for Nicolas Maduro to reject foreign aid and humanitarianism in Venezuela in 2013-2018. The politicization of foreign aid is an important part of the initiatives of donor countries in influencing policy making in recipient countries. Later this issue will develop liberalism, whereas reciprocation the country concerned will receive economic activity units from donor countries [27].

Since 2013 to 2018 there have been some adjustments to the dynamics of domestic politics in Venezuela. Along with the development of time, nationalism is increasingly pressed for the concept of institutional liberalism. The existence of foreign aid and humanitarianism will then be adjusted to new regulations in Venezuela. Nevertheless, these various ideas have not been able to bring change to a better direction, because the government structure has not been effective enough in dealing with various problems that occur. Venezuela under the leadership of Chaves and then transformed into the Maduro era sought to duplicate the economic model of Cuba by giving the state full power to control the economy, taking over the rights of private companies by nationalizing thousands of private and industrial companies into state-owned companies. Chaves also manipulate currencies, control mass media and limit the rights of civilians. Understanding this economic system came to be known as Chavismo which was then continued by the next president Nicolas Maduro [28].

The power acquired by Maduro is nothing more than a political crony facilitated and assisted by Chaves. This power is not obtained based on the principle of who is more appropriate, qualified and has the ability to bring the Venezuelan economy to a better direction. Political factors based on clientelism politics. A system of social order that is formed based on patronage relations between people in power and those desired by the holders of power to rule [28]. In other languages the existing political system is designed only to provide benefits for a handful of people, where power is also highly concentrated in the people closest to the owner of power, so that the main function of the state is not to meet people's needs but to facilitate the political needs of certain groups.

Besides that the resistance of foreign intervention in Venezuela is not an euphoric problem that has developed. This problem occurs due to political learning related to Nicolas Maduro's position as a policy maker. This policy was largely motivated by Maduro as a central position. The potential for foreign intervention in foreign aid has become an important consideration for Nicolas Maduro. In 2005-2018 Venezuela's foreign policy orientation tended to change. The influence of the leadership (top person) of Hugo Chaves to Nicolas Maduro who tends to be anti-Western, makes Venezuela tend to seek substitution of cooperation with non-Western countries, including Iran, China, Japan and several other countries that tend to run towards socialist. 
In the sense of vulnerability there is a phenomenon to justify the state in protecting its valuable assets from annexation of foreign parties in the form of isolation, nationalization or alienation from foreign parties and adverse trade. A different emphasis is not on how rich the country can be said to be strong, but on how independently the country is able to produce its needs. This is due to the basic view of mercantilism that a country that is dependent on other countries ultimately weakens the power of the state itself. Because it indirectly experiences the depletion of its resources or wealth which is nothing but an abstraction of its strength [29].

Capitalism is an economic system in which trade, industry, and production tools are controlled by private owners with the goal of profiting in the market economy. The owner of capital in making efforts to get maximum profit. For Hugo Chaves, capitalism needs to be directed towards liberalism because of the existence of several considerations and adverse effects that are not in accordance with the character of political economy in Venezuela, because it causes several problems.

Thus the decision of Nicolas Maduro in rejecting foreign assistance, both in terms of technical assistance, humanitarian assistance and development assistance is an effort to anticipate the intervention of international actors. In some cases in neighboring countries, including Bolivia, Peru, Nicaragua shows that foreign relations that are not based on equal and technical equality will make leadership difficult in the future [30].

Rejection of assistance to minimize the potential for domestic political intervention is also related to political stability and governance in Venezuela itself. In other words, international actors who seek to implement transparency, accountability and other prerequisites will backfire for Maduro's leadership. For groups of developing countries or new industrial countries these prerequisites will open up various potential problems related to good governance and clean government. In the end this opens up the potential for further intervention, up to the issues of neo-imperialism or hard capitalism. This is the reason for Nicolas Maduro to reject foreign aid and humanitarianism in Venezuela in 2013-2018.

\section{Conclusion}

All Parties who wish to give their assistance to the problems that occur in Venezuela today should immediately determine their choice, want to save the domestic political conditions of Venezuela or want to save Venezuelan citizens who suffer because Shortage of various raw materials. The United States, United Nations, the European Union and other international communities have experience in addressing humanitarian issues around the world, if serious about the handling of Venezuelan humanitarian issues is certainly not a difficult thing. The presence of non-governmental organizations (NGOS) who want to also provide humanitarian assistance should also be supported should not be complicated, because their presence will be very meaningful.

The United States should continue and improve diplomatic leadership and its assistance to respond to the humanitarian crisis of Venezuelakerangka comprehensive policy to address the crisis of migrant and Venezuelan refugees required. Conceptualized two phase response is crucial: "Initial assistance" and "improving stability", depending on the priority and suitability of the task. The United States, Canada, and other Latin American countries as well as the EU and United Nations have experience around the world in dealing with the crisis as it happens in Venezuela. Under the initial response, supporting and engaging local actors is crucial as one upayan to end the sufferings of the uploader at the border. Non-governmental organizations that provide assistance to refugees must be strengthened. The role of religious-based organizations is very basic, international donors must find ways to support their efforts to reduce the impact of malnutrition and the spread of disease. 


\section{References}

[1] Tracy Wilkinson, "U.S. Still Hopes to Salvage OAS Resolution on Venezuela," Los Angeles Times, 2018.

[2] John Otis, "Delegates For Maduro, Guaidó To Meet For Talks On Ending Venezuela's Political Crisis" National Public Radio, 2019. [Online]. Available: https://www.npr.org/2019/05/26/727209098/delegates-for-maduro-guaid-to-meet-for-talks-on-endingvenezuelas-political-cris.

[3] B. E. Bakke, US-Venezuelan Relations. Harvard Model Congress, 2014.

[4] Ciara Nugent, "Why the Threat of U.S. Intervention in Venezuela Revives Historical Tensions in the Region," Time, 2019. [Online]. Available: http://time.com/5512005/venezuela-us-intervention-historylatin-america/.

[5] Frank Mor, "What Would a U.S. Intervention in Venezuela Look L," Foreign Affairs, 2017. .

[6] Michelle Nichols, "United Nations Security Council turns eye to Venezuela crisis," Reuters, 2017.

[7] and C. A. Ben Blanchard, Cheng Fang, "Venezuela Hands China More Oil Presence, but No Mention of New Funds," Reuters, 2018.

[8] Ted Piccone and Harold Trinkuna, "The Cuba-Venezuela Alliance: The Beginning of the En," Washington Office on Latin America, 2014.

[9] CSIS, "Venezuela," Center for Strategic \& International Studies, 2019. [Online]. Available: https://www.csis.org/programs/americasprogram/venezuela?gclid=EAIaIQobChMI8dLYofu_4gIVh91kCh1_ZAPXEAAYAyAAEgIb2PD_BwE

[10] Michael Hernandez, “THE COMPLICATED U.S. RELATIONSHIP WITH VENEZUELA,” Truman Center, 2018. [Online]. Available: http://trumancenter.org/doctrine-blog/the-complicated-u-srelationship-with-venezuela/.

[11] A. \& F. I. Macias, "Tensions between Venezuela and the US keep rising. Here's how they got to this point," CNBC Newsletters, 2019. [Online]. Available: https://www.cnbc.com/2019/04/30/heres-howthe-us-venezuela-relationship-reached-a-boiling-point.html.

[12] "Venezuela crisis: How the political situation escalated," BBC News, 2019. [Online]. Available: https://www.bbc.com/news/world-latin-america-36319877.

[13] Louise Højen, "U . S . -Venezuela Relations in the 21 st Century: MASTER ' S THESIS," Aalborg University, 2015.

[14] C. C. and G. Symon, Qualitative Methods in Organizational Research. London: Sage Publication, 1994.

[15] Mitra Taj, “Lima Group Says Does Not Recognize Venezuela’s Electi,” Reuters, 2018. .

[16] Geoff Ramse, "Assessing the Use of Targeted Sanctions on Venezuelan Officials and Elites," Washington Office on Latin America, 2018.

[17] Shannon O’Ne, “A U.S. Military Intervention in Venezuela Would Be a Disas,” Bloomberg, 2018. .

[18] Harold Trinkuna, "Renminbi Diplomacy? The Limits of China's Influence on Latin America's Domestic Politics," Washington, DC: Brookings Institution, 2016.

[19] M. Webb, J., Gannon-Leary, P. and Bent, "No Title," in Providing effective library services for research, London: Facet, 2007.

[20] Marianna Parraga and Alexandra Ulmer, "Special Report: Vladimir's Venezuela - Leveraging Loans to Caracas, Moscow Snaps up Oil Assets,” Reuters, 2017.

[21] Michelle Nichols, "Russia, China, Others Boycott U.S. Meeting at U.N. on Venezuela," Reuters, 2017. .

[22] U.N. High Commissioner for Human Rights, "Venezuela: Continued impunity amid dismal human rights situation - UN report," 2018. 
[23] Ernesto Londoño and Marlise Simon, “'Neighbors Refer Venezuela to Criminal Court in 'Historic' Rebuke," The New York Times, 2018.

[24] D. Fadillah, "Strategi komunikasi pembentukan budaya organisasi," 2009.

[25] A. Quartely, "Russian Interrest on Venezuela: A New Cold War." [Online]. Available: https://www.americasquarterly.org/content/russian-interests-venezuela-new-cold-war. [Accessed: 03Oct-2018].

[26] TelesurTV, "Venezuela and International Palestine Solidarity Sign." [Online]. Available: https://www.telesurtv.net/english/news/Venezuela-and-Palestine-Express-Solidarity-Sign-MutualHealth-Agreement-20171026-0034.html. [Accessed: 09-Oct-2018].

[27] Luis Almagro, "Venezuela Can’t Become Another Rwand," Americas Quarterl, 2018.

[28] Aljazeera, "Venezuela Crisis: Explaining From Begining." [Online]. Available: https://www.aljazeera.com/indepth/features/2017/04/venezuela-happening-170412114045595.html. [Accessed: 08-Oct-2018].

[29] Springer Link, "State and Power Vulnerability." [Online]. Available: https://link.springer.com/chapter/10.1007/978-3-319-48018-3_3. [Accessed: 06-Oct-2018].

[30] Miguel Angel Latouche, "Venezuela Is Now a Dictatorship," The Conversation, 2018. 